\title{
Substrate Quality Effects on Decomposition of Three Livestock Manure Composts with Similar Stability Degree in an Acid Loamy Soil
}

\author{
Sang-Sun Lim ${ }^{\dagger}$, Jae-Woon Jung ${ }^{1 \dagger}$, Woo-Jung Choi*, and Hee-Myong Ro ${ }^{2}$ \\ Department of Rural \& Biosystems Engineering, Chonnam National University, Gwangju 500-757, Korea \\ ${ }^{1}$ Yeongsan River Environment Research Center, Gwangju 500-480, Korea, ${ }^{2}$ Department of Agricultural \\ Biotechnology and Research Institute of Agriculture and Life Sciences, Seoul National University, \\ Seoul 151-921, Korea, 'Lim SS and Jung JW contributed equally (Co-first authors)
}

\begin{abstract}
Decomposition of compost applied to soils is affected basically by its biological stability; but, many other chemical properties of the compost may also influence compost organic- $\mathrm{C}$ mineralization. This study was conducted to investigate the principal substrate quality factors of composts that determine $\mathbf{C}$ mineralization of compost with similar stability degree (SD). Three composts samples with similar SD but different chemical properties such as $\mathrm{pH}, \mathrm{C} / \mathrm{N}, \mathrm{K}_{2} \mathrm{SO}_{4}$-extractable $\mathrm{C}$, and molar ratio of $\mathrm{NH}_{4}{ }^{+}$to $\mathrm{NO}_{3}{ }^{-}$were mixed with an acid loamy soil and $\mathrm{CO}_{2}$ emission was monitored during the laboratory incubation for 100 days. Temporal pattern of cumulative compost organic- $\mathrm{C}$ mineralization expressed as $\%$ of total organic $\mathrm{C}$ $\left(C_{\%}\right.$ Toc) followed double exponential first order kinetics model and the $C_{\%}$ roc ranged from 4.8 to $11.8 \%$ at the end of incubation. The pattern of $\mathrm{C}_{\%}$ тос among the composts was not coincident with the SD pattem (40.1 to 58.6\%) of the composts; e.g. compost with the lowest SD resulted in the least $\mathrm{C}_{\%}$ toc and vice versa. This result indicates that SD of compost can not serve as a concrete predictor of compost mineralization as SD is subject not only to maturity of compost but also to characteristics of co-composting materials such as rice hull (low SD) and sawdust (high SD). Meanwhile, such pattem of $\mathrm{C}_{\%}$ тос collaborated with $\mathrm{pH}, \mathrm{C} / \mathrm{N}$, $\mathrm{K}_{2} \mathrm{SO}_{4}$-extractable $\mathrm{C}$, and molar ratio of $\mathrm{NH}_{4}{ }^{+}$to $\mathrm{NO}_{3}{ }^{-}$of the composts that are regarded as chemical indices of the progress of composting. Therefore, for better prediction of compost mineralization in soils, it is necessary to consider both $\mathrm{SD}$ and other chemical indices $\left(\mathrm{pH}, \mathrm{C} / \mathrm{N}\right.$, and molar ratio of $\mathrm{NH}_{4}{ }^{+}$to $\left.\mathrm{NO}_{3}{ }^{-}\right)$.
\end{abstract}

Key words: $\mathrm{CO}_{2}$ emission, First-order kinetics, Mineralizable $\mathrm{C}$ pool, Mineralization rate, Livestock manure compost, Stability degree

\section{Introduction}

Composting converts livestock manure into a biochemically stable organic material that can be readily stored, easily handled, and uniformly applied to soils with little odor (Tittarelli et al., 2007). The application of compost supplies plants with nutrients, maintains soil organic matter levels, and ultimately improves plant growth (Stamatiadis et al., 1999; Courtney and Mullen, 2008). As nutrients in the composts become available via microbial decomposition of various fractions of organic matter, the understanding of $\mathrm{C}$ mineralization in compost-amended soils is critical to estimating the levels of nutrient release from composts

\footnotetext{
Received : July 7. 2011 Accepted : July 26. 2011

*Corresponding author : Phone: +82625302153

E-mail: wjchoi@chonnam.ac.kr
}

(Castellanos and Pratt, 1981).

The characteristics of $\mathrm{C}$ mineralization of compost in soils have been evaluated by determining soil $\mathrm{CO}_{2}$ respiration in incubation experiments (e.g. Bernal et al., 1998; Busby et al., 2007). First-order kinetic models are generally utilized to describe $\mathrm{C}$ mineralization due to their versatility, frequently with the separation of organic $\mathrm{C}$ into two pools with different biodegradability; these are referred to as the rapidly decomposable and slowly decomposable pools (Boyle and Paul, 1989; Hadas and Portnoy, 1994; Bernal et al., 1998; Aslam et al., 2008). The pool sizes of the mineralizable $\mathrm{C}$ fractions and their mineralization rates can be determined by fitting the kinetic equations to cumulative soil respiration curves (Bernal et al., 1998).

Carbon mineralization, which is expressed in terms of the quantity of $\mathrm{CO}_{2}-\mathrm{C}$ generated from soils amended with organic materials, including manure, municipal solid waste, 
and their compost, depends largely on the compounds composition (e.g. lignin and cellulose) of the organics employed (e.g. Levi-Minzi, et al., 1990; Ajwa and Tabatabai, 1994). For composts, organic $C$ mineralization in the compost-amended soils is believed to be affected principally by the biological stability of the compost; e.g. a greater production of $\mathrm{CO}_{2}$ with less stable compost (Bernal et al., 1998; García-Gómez et al., 2003; Aslam et al., 2008). For example, Bernal et al. (1998) previously suggested that when $\mathrm{C}$ mineralized is higher than $25 \%$ of the total organic $\mathrm{C}$ (TOC) applied, the composts could be assumed to be at a low degree of stability.

However, it is still doubtable if $\mathrm{C}$ mineralization of compost amended in soils is determined primarily by compost stability as not only stability but also other substrate (compost) quality including $\mathrm{C} / \mathrm{N}$, available $\mathrm{N}$ concentration $\left(\mathrm{NH}_{4}{ }^{+}\right.$and $\left.\mathrm{NO}_{3}{ }^{-}\right)$, and extractable organic $\mathrm{C}$ may certainly influence compost organic-C mineralization particularly when the composts being applied are biologically stable; i.e. less than $25 \%$ of TOC of compost is subject to decomposition according to Bernal et al. (1998). Therefore, this study was conducted to investigate the principal substrate quality factors of composts that determine $\mathrm{C}$ mineralization of compost in soils when the composts being applied are biologically stable judging from their stability degree.

\section{Materials and Methods}

Soil Soil samples were collected from the surface layer $(0$ to $15 \mathrm{~cm})$ of the agricultural soils in the experimental farm at the Jeonnam Agricultural Research \& Extension Service $\left(126^{\circ} 49^{\prime} 46^{\prime \prime} \mathrm{E}, 35^{\circ} 01^{\prime} 24^{\prime \prime} \mathrm{N}\right)$. The soil was classified as Ultisol (fine, mesic family of Typic Hapludults) in the USA Soil Taxonomy. The collected soils were air-dried, passed through a 2-mm sieve, and utilized for the analysis of selected properties and for the incubation study (Table 1).

Composts Ten compost samples were purchased from local companies. The compost samples were freeze-dried, crushed $(<2 \mathrm{~mm})$, and analyzed for stability degree (SD) following the procedures provided by López et al. (2010) that is modified from Klason lignin method. Briefly, SD was calculated as $\%$ of resistant organic matter (ROM) to total organic matter (TOM) of compost; ROM represents $\mathrm{OM}$ fractions that are not hydrolysable by acid $\left(\mathrm{H}_{2} \mathrm{SO}_{4}\right)$, and the detailed procedures are provided in López et al. (2010). Among the ten composts, three composts were
Table 1. Selected physico-chemical properties of soils used.

\begin{tabular}{lc}
\hline \hline Properties $^{\dagger}$ & Ultisol \\
\hline Texture & Loam \\
& $(23.4: 45.2: 31.4)$ \\
$\mathrm{pH}_{1: 5}$ & $5.6(0.2)$ \\
Total organic C $\left(\mathrm{g} \mathrm{C} \mathrm{kg}^{-1}\right)$ & $19.1(0.8)$ \\
Total N $\left(\mathrm{g} \mathrm{N} \mathrm{kg}^{-1}\right)$ & $2.4(0.1)$ \\
$\mathrm{K}_{2} \mathrm{SO}_{4}$-extractable organic C $\left(\mathrm{g} \mathrm{C} \mathrm{kg}^{-1}\right)$ & $0.22(0.01)$ \\
$\mathrm{KCl}^{-}$extractable $\mathrm{NH}_{4}^{+}\left(\mathrm{mg} \mathrm{N} \mathrm{kg}^{-1}\right)$ & $8.5(0.3)$ \\
$\mathrm{KCl}^{-}$extractable NO \\
$\mathrm{C}^{-}\left(\mathrm{mg} \mathrm{N} \mathrm{kg}^{-1}\right)$ & $357.3(14.3)$ \\
$\mathrm{WHC}\left(\mathrm{kg} \mathrm{kg}^{-1}\right)$ & $8.0(0.3)$ \\
\hline
\end{tabular}

${ }^{\dagger}$ All analyses were conducted on triplicate samples for each soil. Texture was in USDA classifications and the values in parentheses are the $\%$ distributions of clay:silt:sand determined by the pipette method (Gee and Bauder, 1986); $\mathrm{pH}$ at a 1-to-5 ratio of soil-to-water; total organic $\mathrm{C}$ and $\mathrm{N}$ concentrations via a combustion method (Nelson and Sommers, 1996); $\mathrm{K}_{2} \mathrm{SO}_{4}$ extractable organic $\mathrm{C}$ with a TOC analyzer after $\mathrm{K}_{2} \mathrm{SO}_{4}$ extraction at 1-to-5 of soil-to- $\mathrm{K}_{2} \mathrm{SO}_{4}\left(1\right.$ mole $\left.\mathrm{L}^{-1}\right)$ ratio (Choi and Chang, 2005); $\mathrm{KCl}$-extractable $\mathrm{NH}_{4}{ }^{+}$and $\mathrm{NO}_{3}{ }^{-}$concentrations using the steam distillation method after $\mathrm{KCl}$ extraction at a 1-to-5 soil-to-KCl (2 mole $\mathrm{L}^{-1}$ ) ratio (Mulvaney, 1996); WHC (water holding capacity) with the gravimetric method using a funnel (Fierer and Schimel, 2002).

selected that showed relatively high SD over $40 \%$ for incubation experiment. The selected composts were analyzed for $\mathrm{pH}$, total organic $\mathrm{C}$, total $\mathrm{N}, \mathrm{C} / \mathrm{N}, \mathrm{K}_{2} \mathrm{SO}_{4}$-extractable organic $\mathrm{C}$, and $\mathrm{KCl}$-extractable $\mathrm{N}\left(\mathrm{NH}_{4}{ }^{+}\right.$and $\left.\mathrm{NO}_{3}{ }^{-}\right)$(Table 2). Comparing among the composts, compost $\mathrm{A}$ had a relatively low $\mathrm{pH}, \mathrm{C} / \mathrm{N}$, extractable $\mathrm{C}$, and molar ratio of $\mathrm{NH}_{4}^{+}$to $\mathrm{NO}_{3}^{-}$(Table 2).

Laboratory Incubation A laboratory incubation was conducted using 1-L Mason jars. A total of 12 jars were prepared: four treatments (one without composts and three for composts) $\times$ three replicates. Thirty grams of soil (dry basis) were placed in a $100-\mathrm{mL}$ beaker and distilled water was added to bring the moisture content to $60 \%$ of the water holding capacity (WHC) of the soil, and then preincubated for 5 days at $25 \pm 1{ }^{\circ} \mathrm{C}$ in darkness to restore the microbial activity of the soils. Afterwards, each $1 \mathrm{~g}$ of compost was mixed with the soil (30 g) for compost treatments, and the moisture content of the mixture was re-adjusted to $60 \% \mathrm{WHC}$. The application rate of compost is equivalent to $8.86,9.89$, and $11.17 \mathrm{~g} \mathrm{C} \mathrm{kg}^{-1}$ soil for composts $\mathrm{A}, \mathrm{B}$, and $\mathrm{C}$, respectively. Both the beaker containing the soils and a $25-\mathrm{mL}$ vial containing $20 \mathrm{~mL}$ of 
Table 2 Selected chemical properties of composts used ${ }^{\dagger}$.

\begin{tabular}{|c|c|c|c|c|c|c|c|c|c|c|}
\hline \multirow{2}{*}{ Compost } & \multirow{2}{*}{$\begin{array}{c}\text { Composting } \\
\text { materials }\end{array}$} & \multirow{2}{*}{$\begin{array}{l}\text { Stability } \\
\text { Degree }\end{array}$} & \multirow{2}{*}{$\mathrm{pH}_{1: 10}$} & \multirow{2}{*}{$\begin{array}{c}\text { Total } \\
\text { organic } \mathrm{C}\end{array}$} & \multirow{2}{*}{ Total N } & \multirow{2}{*}{$\mathrm{C} / \mathrm{N}$} & \multirow{2}{*}{$\begin{array}{c}\mathrm{K}_{2} \mathrm{SO}_{4} \\
\text { extractable } \mathrm{C}\end{array}$} & \multicolumn{3}{|c|}{$\mathrm{KCl}$ extractable $\mathrm{N}$} \\
\hline & & & & & & & & $\mathrm{NH}_{4}^{+}$ & $\mathrm{NO}_{3}^{-}$ & $\mathrm{NH}_{4}^{+} / \mathrm{NO}_{3}^{-}$ \\
\hline & $\mathrm{v} / \mathrm{v} \%$ composition & $\%$ & & $\mathrm{~g} \mathrm{C} \mathrm{kg}^{-1}$ & $\mathrm{~g} \mathrm{~N} \mathrm{~kg}^{-1}$ & & $\mathrm{~g} \mathrm{C} \mathrm{kg}^{-1}$ & ----- g & $\mathrm{kg}^{-1}$ & \\
\hline A & $\begin{array}{l}\text { Pig manure (50) } \\
\text { Rice hull } \\
\text { (30)/Sawdust (20) }\end{array}$ & $\begin{array}{l}40.1 \\
(0.9)\end{array}$ & $\begin{array}{c}8.1 \\
(0.1)\end{array}$ & $\begin{array}{l}265.7 \\
(17.8)\end{array}$ & $\begin{array}{l}23.0 \\
(1.5)\end{array}$ & $\begin{array}{l}11.5 \\
(0.8)\end{array}$ & $\begin{array}{l}1.7 \\
(0.0)\end{array}$ & $\begin{array}{c}0.8 \\
(0.06)\end{array}$ & $\begin{array}{c}2.5 \\
(0.17)\end{array}$ & $\begin{array}{c}0.3 \\
(0.02)\end{array}$ \\
\hline B & $\begin{array}{c}\text { Cattle and pig } \\
\text { manure }(50) \\
\text { Sawdust }(50)\end{array}$ & $\begin{array}{l}49.7 \\
(2.3)\end{array}$ & $\begin{array}{c}9.2 \\
(0.2)\end{array}$ & $\begin{array}{l}296.6 \\
(5.3)\end{array}$ & $\begin{array}{l}13.7 \\
(0.2)\end{array}$ & $\begin{array}{l}21.7 \\
(0.4)\end{array}$ & $\begin{array}{c}4.1 \\
(0.07)\end{array}$ & $\begin{array}{c}0.5 \\
(0.01)\end{array}$ & $\begin{array}{c}0.04 \\
(0.001)\end{array}$ & $\begin{array}{l}10.9 \\
(0.2)\end{array}$ \\
\hline $\mathrm{C}$ & $\begin{array}{l}\text { Pig manure (45) } \\
\text { Sawdust }(55)\end{array}$ & $\begin{array}{l}58.6 \\
(4.8)\end{array}$ & $\begin{array}{c}8.9 \\
(0.3)\end{array}$ & $\begin{array}{l}335.2 \\
(11.4)\end{array}$ & $\begin{array}{l}14.6 \\
(0.5)\end{array}$ & $\begin{array}{l}22.9 \\
(0.8)\end{array}$ & $\begin{array}{l}4.8 \\
(0.5) \\
\end{array}$ & $\begin{array}{c}0.2 \\
(0.01)\end{array}$ & $\begin{array}{c}0.004 \\
(0.000)\end{array}$ & $\begin{array}{l}55.8 \\
(1.9)\end{array}$ \\
\hline
\end{tabular}

${ }^{\dagger}$ All analyses were conducted on triplicate compost samples. $\mathrm{pH}$ was measured at a 1-to-10 ratio of compost-to-water; organic $\mathrm{C}$ and total $\mathrm{N}$ concentrations with a combustion method (Nelson and Sommers, 1996); $\mathrm{K}_{2} \mathrm{SO}_{4}$-extractable organic $\mathrm{C}$ with a TOC analyzer after $\mathrm{K}_{2} \mathrm{SO}_{4}$ extraction at 1-to-10 of soil-to- $\mathrm{K}_{2} \mathrm{SO}_{4}\left(0.5\right.$ mole $\left.\mathrm{L}^{-1}\right)$ ratio (Choi and Chang, 2005); KCl-extractable $\mathrm{NH}_{4}^{+}$and $\mathrm{NO}_{3}^{-}$ concentrations using the steam distillation method after $\mathrm{KCl}$ extraction at 1-to-10 of soil-to-KCl (2 mole L $\left.{ }^{-1}\right)$ ratio (Mulvaney, 1996), respectively.

$1 \mathrm{~N} \mathrm{NaOH}\left(\mathrm{CO}_{2}\right.$ trap) were placed into the Mason jars, and the jars were sealed with air-tight screw-top lids. The jars were incubated for 100 days in darkness at $25 \pm 1^{\circ} \mathrm{C}$. During incubation, the jars were opened for 10 minutes every other day to maintain an adequate $\mathrm{O}_{2}$ level. In a previous study, the $\mathrm{CO}_{2}$ loss during the aeration was estimated to be negligible (Lee et al., 2011). At 7, 21, 35, 49,75 , and 100 days of incubation, the vial containing the $\mathrm{NaOH}$ solution was removed from the jar and utilized for the analysis of $\mathrm{CO}_{2}$, and a new vial with fresh $\mathrm{NaOH}$ solution was placed back in the jar at each sampling (except the last sampling at 100 days). Soil water content was adjusted by adding distilled water to the initial weight of the soil container at each sampling.

$\mathrm{CO}_{2}$ Measurement and Calculation The amount of $\mathrm{CO}_{2}$ - $\mathrm{C}$ trapped in the $\mathrm{NaOH}$ solution was determined via the titration of the solution with $1 \mathrm{~N} \mathrm{HCl}$ solution after the addition of $20 \mathrm{~mL}$ of $1 \mathrm{~N} \mathrm{BaCl}_{2}$ (Choi and Chang, 2005). The rate of $\mathrm{CO}_{2}$ emission was expressed as $\mathrm{mg} \mathrm{C} \mathrm{kg}^{-1}$ soil day $^{-1}$. The amount of $\mathrm{C}$ emitted as $\mathrm{CO}_{2}$ from the applied compost was calculated as the difference in the amount of $\mathrm{CO}_{2}-\mathrm{C}$ evolved between the compost-amended soil and the control soil without compost, and the priming effect (influence of added compost on soil $\mathrm{C}$ mineralization in this study) was assumed to be negligible (Sinha et al., 1977; Bernal et al., 1998). The cumulative $\mathrm{CO}_{2}-\mathrm{C}\left(\mathrm{C}_{\mathrm{cum}}\right)$ emitted over the 100-day incubation was calculated. For comparison among the composts, the $\mathrm{C}_{\text {cum }}$ was expressed as the $\%$ of added total organic $\mathrm{C}$ (TOC) of the composts $\left(\mathrm{C}_{\% \mathrm{TOC}}\right)$.
Kinetic Model Fitting To estimate the pool size of mineralizable organic $\mathrm{C}$ and the mineralization rate constant, the data on cumulative $\mathrm{CO}_{2}-\mathrm{C}$ evolution was fitted to the double exponential first-order kinetic model with the Fit Curve procedures of SigmaPlot 10.0 (Systat Software Inc., IL), which uses the Marquardt-Levenberg algorithm and an iterative process to determine the parameter values that minimize the residual sum of squares. The double exponential model separates the mineralizable organic $\mathrm{C}$ into rapidly and slowly mineralizable pools as follows:

$$
\mathrm{C}_{\% \text { TOC }}=\mathrm{C}_{\mathrm{R}}\left[1-\exp \left(-\mathrm{k}_{\mathrm{R}} \mathrm{t}\right)\right]+\mathrm{C}_{\mathrm{S}}\left[1-\exp \left(-\mathrm{k}_{\mathrm{S}} \mathrm{t}\right)\right]
$$

in which $\mathrm{C}_{\% \mathrm{TOC}}$ is the cumulative $\%$ of $\mathrm{C}$ mineralized from the compost at time $t ; C_{R}$ and $C_{S}$ are the sizes of rapid and slow pools of mineralizable organic $\mathrm{C}$ (as \% of TOC), respectively; and $\mathrm{k}_{\mathrm{R}}$ and $\mathrm{k}_{\mathrm{S}}$ are the corresponding mineralization rate constants $\left(\mathrm{day}^{-1}\right)$ for each pool. Generally, the automatically estimated parameters proved acceptable; however, in some cases, particularly in cases in which $k_{R}$ and $\mathrm{ks}_{\mathrm{s}}$ were greater than a few orders of magnitude, the manual adjustment of the initial $\mathrm{k}_{\mathrm{R}}$ and $\mathrm{k}_{\mathrm{S}}$ values was required to generate sensible results (Wang et al., 2004).

Statistical Analysis One-way ANOVA on $\mathrm{C}_{\text {cum }}, \mathrm{C}_{\%}$ TOC, and kinetics parameters $\left(\mathrm{C}_{0}, \mathrm{k}_{0}, \mathrm{C}_{\mathrm{R}}, \mathrm{k}_{\mathrm{R}}, \mathrm{C}_{\mathrm{S}}\right.$, and $\left.\mathrm{k}_{\mathrm{S}}\right)$ was conducted to evaluate the effects of compost type using the GLM procedure in the SPSS 17.0 package (SPSS Inc., Chicago. IL, USA). When the treatment effects were significant, the means were separated by Duncan's multiple range tests. The significance of the first-order kinetic 
model was analyzed by an $F$-test. The level of significance established for all statistical tests was $\alpha=0.05$.

\section{Results and Discussion}

Temporal Pattem of $\mathrm{CO}_{2}$ Emission Rate The maximum rate of $\mathrm{C}$ mineralization was noted during the first week of incubation particularly for the treatments with composts $\mathrm{B}$ and $\mathrm{C}$; thereafter, the $\mathrm{C}$ mineralization rate gradually decreased with elapse of incubation time (Fig. 1). Such temporal pattern of $\mathrm{C}$ mineralization, an initial flush of $\mathrm{CO}_{2}-\mathrm{C}$ followed by a gradual decrease or relatively constant mineralization rate, is not unusual and reported by other studies (e.g. Levi-Minizi et al., 1990; Ajwa and Tabatabai, 1994; Bernal et al., 1998; Aslam et al., 2008). The initial flush of $\mathrm{CO}_{2}$ emission is believed to represent the presence of readily decomposable organic carbon (e.g. $\mathrm{K}_{2} \mathrm{SO}_{4}$ extractable organic $\mathrm{C}$ in our study) in the composts that stimulates microbial activities in the soils immediately
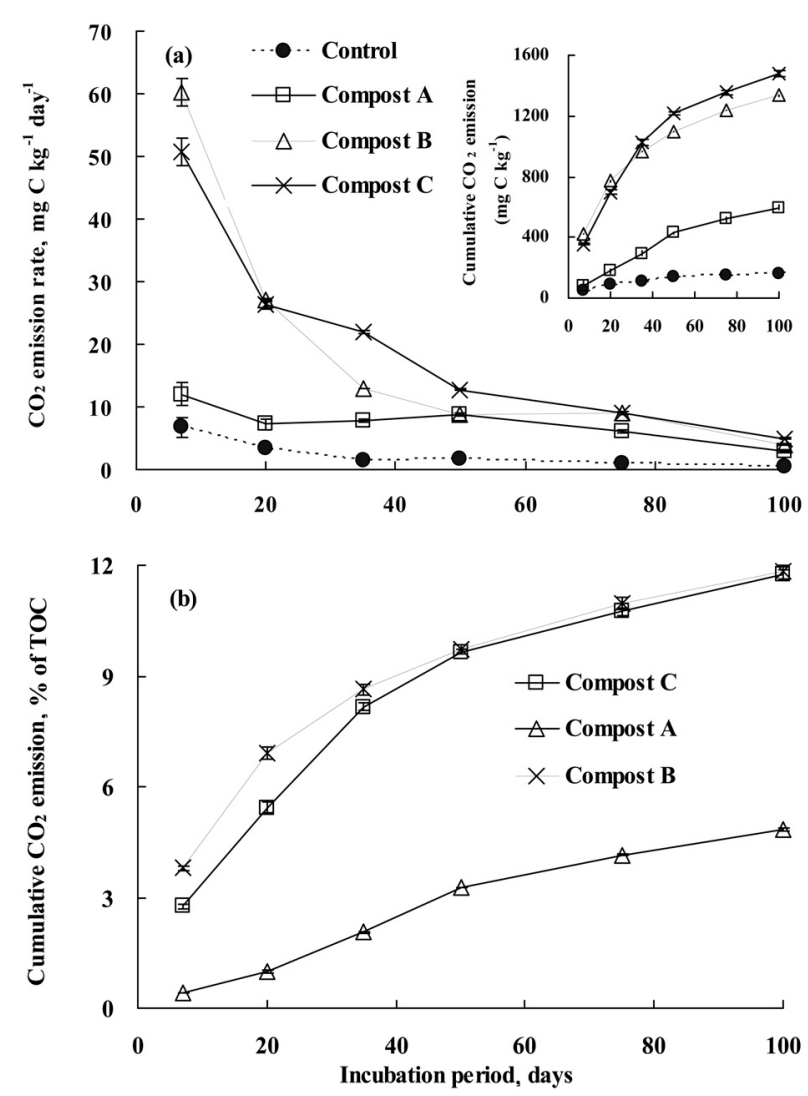

Fig. 1. (a) $\mathrm{CO}_{2}$ emission rate from the soil amended with or without composts (cumulative $\mathrm{CO}_{2}$ emission from both soil and compost is depicted in the small figure) and (b) cumulative $\mathrm{CO}_{2}$ emission only from compost expressed as \%of total organic C (TOC) of compost applied. Vertical bars are standard emors of the means. after application of the composts (Bernal et al., 1998). Therefore, the diminutive $\mathrm{CO}_{2}$ peak of the soil with compost A during the early incubation period could be attributed primarily to its low $\mathrm{K}_{2} \mathrm{SO}_{4}$ extractable organic $\mathrm{C}(1.7 \mathrm{~g}$ $\mathrm{C} \mathrm{kg}^{-1}$, see Table 2). A steady emission of $\mathrm{CO}_{2}$ from organicsamended soils following the initial flush is also widely reported and ascribed to depletion of readily decomposable organic $\mathrm{C}$ during the early incubation period (Bernal and Kirchmann, 1992; Kirchmann and Lundvall, 1993; Bernal et al., 1998; Rochette et al., 2006).

\section{Cumulative $\mathrm{CO}_{2}$ Emission and Its Relation with Substrate}

Quality The $\mathrm{C}_{\text {cum }}$ over time exhibited an exponential pattern (small figure in Fig. 1a) and were 165.7, 595.0, 1333.9, and $1478.1 \mathrm{mg} \mathrm{C} \mathrm{kg}^{-1}$ for control, compost A, B, and $\mathrm{C}$, respectively, at the end of incubation, and these were significantly $(P<0.001)$ different among the treatments (Table 3). The greatest $\mathrm{C}_{\text {cum }}$ for compost $\mathrm{C}$ followed by compost $\mathrm{B}$ and $\mathrm{A}$ is well corresponding to the amount of $\mathrm{C}$ applied as compost: $8.86,9.89$, and $11.17 \mathrm{~g} \mathrm{C} \mathrm{kg}^{-1}$ soil for composts $\mathrm{A}, \mathrm{B}$, and $\mathrm{C}$, respectively. Therefore, to investigate the effect of substrate quality on compost organic-C mineralization, it was necessary to express the $\mathrm{C}_{\text {cum }}$ as $\%$ of TOC of compost ( $\mathrm{C}_{\% \text { TOC }}$ ), and the values were $4.8,11.8$, and $11.7 \%$ for compost $\mathrm{A}, \mathrm{B}$, and $\mathrm{C}$, respectively (Table 3 ). These values are within the range of 2.0 to $39.0 \%$ reported for matured composts by Bernal et al. (1998) and Helgason et al. (2005), but lower than the values (from 21 to $62 \%$ ) reported for a variety of non-composted organic materials, including plant residues, animal manure, and sewage sludge (Ajwa and Tabatabai, 1994). Through an

Table 3. The cumulative amount of $\mathrm{C}$ mineralized $(\mathrm{mg} \mathrm{CO}-\mathrm{C}$ $\mathrm{kg}^{-1}$ ) from the composts amended in the soils during the 100 days of incubation and its percentage relative to the total organic $\mathrm{C}(\%$ of TOC) in the composts.

\begin{tabular}{lcc}
\hline \hline \multirow{2}{*}{ Treatment } & \multicolumn{2}{c}{ Cumulative $\mathrm{CO}_{2}$-C } \\
\cline { 2 - 3 } & Amount per soil & $\begin{array}{c}\text { Percentage of } \\
\text { compost TOC }\end{array}$ \\
\hline Control & $165.7(1.1) \mathrm{a}$ & Not applicable \\
Compost A & $595.0(3.9) \mathrm{b}$ & $4.8(0.03) \mathrm{a}$ \\
Compost B & $1333.9(18.3) \mathrm{c}$ & $11.8(0.18) \mathrm{b}$ \\
Compost C & $1478.1(14.5) \mathrm{c}$ & $11.7(0.12) \mathrm{b}$ \\
Effects & Probability $>F$ & \\
Treatment & $<0.001$ & $<0.001$ \\
\hline Values
\end{tabular}

Values followed by the same letter are not statistically different at $\alpha=0.05$. 
incubation study using compost samples at different stages of composting (from initial to maturity stages), Bernal et al. (1998) suggested that a $\mathrm{C}_{\% \text { TOC }}$ of over $25 \%$ after 70 days of incubation might indicate the pre-maturity of the composts. Therefore, all of the composts utilized in this study could be considered to be mature or stable.

Meanwhile, considering the lower SD of compost A (40.1\%, see Table 2) than composts B (49.7\%) and C

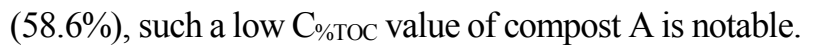
Assuming that the three composts used in our study are biological stable judging from the $\mathrm{C}_{\% \text { тоС }}$ as suggested by Bernal et al. (1998), such discordant relationship between $\mathrm{SD}$ and $\mathrm{C}_{\% \mathrm{TOC}}$ suggests that other factors can be more critical for $\mathrm{C}$ mineralization of compost. In the present study, the considerably lower $\mathrm{C}_{\% \text { Tос }}$ of compost $\mathrm{A}$ than those of composts $\mathrm{B}$ and $\mathrm{C}$ collaborates with its low $\mathrm{pH}$, $\mathrm{C} / \mathrm{N}, \mathrm{K}_{2} \mathrm{SO}_{4}$-extractable $\mathrm{C}$, and $\mathrm{NH}_{4}{ }^{+} / \mathrm{NO}_{3}^{-}$(Table 2). First of all, $\mathrm{K}_{2} \mathrm{SO}_{4}$-extractable $\mathrm{C}$ concentrations of composts $\mathrm{A}, \mathrm{B}$, and $\mathrm{C}$ were $1.7,4.1$, and $4.8 \mathrm{~g} \mathrm{C} \mathrm{kg}^{-1}$ (Table 2) and these amounts are equivalent to $0.63,1.38$, and $1.42 \%$ of TOC. As $\mathrm{K}_{2} \mathrm{SO}_{4}$-extractable $\mathrm{C}$ is considered to be readily decomposable organic $\mathrm{C}$ pool, therefore, the low extractable C concentration of compost A might have led to diminutive $\mathrm{C}_{\% \text { TOC }}$ (Choi and Chang, 2005).

Meanwhile, $\mathrm{pH}, \mathrm{C} / \mathrm{N}$, and $\mathrm{NH}_{4}^{+} / \mathrm{NO}_{3}^{-}$are closely associated with progress of composting stages and therefore, they may serve indicators of compost maturity and thus decomposability of the composts (Tittarelli et al., 2007). As the $\mathrm{pH}$ of the composting mixture tends to increase via the mineralization of organic $\mathrm{N}$ and protonation $\left(\mathrm{R}-\mathrm{NH}_{2} \rightarrow\right.$ $\mathrm{NH}_{4}{ }^{+}+\mathrm{OH}$ ) in the initial stage, followed by a progressive reduction as the result of nitrification $\left(\mathrm{NH}_{4}{ }^{+} \rightarrow \mathrm{NO}_{3}{ }^{-}+\right.$ $2 \mathrm{H}^{+}$) and organic acid production, pre-matured compost may show a relatively high $\mathrm{pH}$ (Kim et al., 2008; Leconte et al., 2009). In this context, it is plausible that compost A $(\mathrm{pH} 8.1)$ is regarded as more mature than compost $\mathrm{B}$ (9.2) and $C$ (8.9). The narrow $C / N$ of compost seems to be another indicator of high maturity of compost $\mathrm{A}$ as the $\mathrm{C} / \mathrm{N}$ of composting materials tends to decrease with the progress of microbial decomposition of the materials due to the faster loss of $\mathrm{C}$ relative to $\mathrm{N}$ (Kim et al., 2008). Regarding the molar ratio of $\mathrm{NH}_{4}^{+}$to $\mathrm{NO}_{3}^{-}$, Helgason et al. (2005) reported that $\mathrm{C}$ mineralization of cattle manure composts applied to soils is proportional to the $\mathrm{NH}_{4}{ }^{+}$-to$\mathrm{NO}_{3}{ }^{-}$ratio of the composts. This is attributable to the fact that active nitrification (oxidation of $\mathrm{NH}_{4}^{+}$to $\mathrm{NO}_{3}{ }^{-}$) occurs during the middle or late phase of composting following early decomposition of organic matter (Kim et al., 2008). Therefore, the lower $\mathrm{NH}_{4}{ }^{+}$-to- $\mathrm{NO}_{3}{ }^{-}$ratio of compost A represents changes in the concentrations of $\mathrm{NH}_{4}{ }^{+}$(decrease) and $\mathrm{NO}_{3}^{-}$(increase) with compost maturing.

The discrepancy between SD and maturity indices of composts observed in our study could be due to different type and mixing rate of co-composting materials such as rice hull and sawdust (Table 2). For compost A, rice hull and sawdust were mixed with pig manure at 30 and $20 \mathrm{v} / \mathrm{v}$ $\%$, respectively; meanwhile for composts B and C, 50 and $55 \mathrm{v} / \mathrm{v} \%$ of sawdust were mixed with livestock manure (Table 2). López et al. (2010) investigated SD of 25 types of composting materials including rice hull and wood materials and reported that $\mathrm{SD}$ of rice hull was $33 \%$ that is much lower than that (around 60\%) wood materials. In the present study, the lower SD of compost A compared with those of composts $\mathrm{B}$ and $\mathrm{C}$ should be primarily due to relatively low $\mathrm{SD}$ of rice hull that used as co-composting materials. In this context, as our results in combination

Table 4. Parameter values $\left(C_{R}\right.$, rapidly mineralizable $C$ pool; $C_{S}$, slowly mineralizable $C$ pool; $k_{r}$, mineralization rate constant of $\mathrm{C}_{\mathrm{R}}$; $\mathrm{k}_{S}$, mineralization rate constant of $\mathrm{C}_{S}$ ) of the double first-order equation model and $F$-values for $\mathrm{CO}_{2}-\mathrm{C}_{\text {mineralization }}$ of the composts in three soils.

\begin{tabular}{|c|c|c|c|c|c|}
\hline \multirow{2}{*}{ Treatment } & \multicolumn{2}{|c|}{ Rapid pool } & \multicolumn{2}{|c|}{ Slow pool } & \multirow{2}{*}{$F^{\dagger}$} \\
\hline & $\mathrm{C}_{\mathrm{R}}$ & $\mathrm{k}_{\mathrm{R}}$ & $\mathrm{C}_{\mathrm{S}}$ & $\mathrm{ks}_{\mathrm{S}}$ & \\
\hline & $\%$ of TOC & day $^{-1}$ & $\%$ of $\mathrm{TOC}$ & day $^{-1}$ & \\
\hline Compost A & $5.2 b$ & $0.016 \mathrm{a}$ & $6.1 \mathrm{a}$ & $0.003 \mathrm{a}$ & $67.7^{* *}$ \\
\hline Compost B & $4.5 b$ & $0.144 b$ & $9.8 \mathrm{~b}$ & $0.020 \mathrm{~b}$ & $7924.1^{* * *}$ \\
\hline Compost C & $2.2 \mathrm{a}$ & $0.132 b$ & $11.6 \mathrm{~b}$ & $0.026 \mathrm{~b}$ & $369.2^{* * *}$ \\
\hline Effects & Probability $>F$ & & & & \\
\hline Treatment & $<0.001$ & $<0.001$ & $<0.001$ & $<0.001$ & \\
\hline
\end{tabular}

Values followed by the same letter are not statistically different at $\alpha=0.05$.

${ }^{*} P<0.05,{ }^{* *} P<0.01,{ }^{* * *} P<0.001$ 
with López et al. (2010) suggest that SD of compost is subject to not only compost maturity but also the type of co-composting materials, SD of compost alone can not be used in predicting compost organic-C mineralization. Therefore, other substrate quality indices such as $\mathrm{pH}, \mathrm{C} / \mathrm{N}$, and $\mathrm{NH}_{4}{ }^{+} / \mathrm{NO}_{3}{ }^{-}$also needs to be considered to better predict compost decomposition.

Mineralization Kinetics Overall, C mineralization was well fit with the double exponential first-order kinetic model, and the total mineralizable organic $\mathrm{C}$ pool in the composts was separated successfully into rapidly and slowly mineralizable (Table 4). The sizes of rapid $\left(C_{R}\right)$ and slow pool $\left(\mathrm{C}_{\mathrm{S}}\right)$ of mineralizable $\mathrm{C}$ of composts $\mathrm{A}, \mathrm{B}$, and $C$ were $5.2,4.5$, and $2.2 \%$ and $6.1,9.8$, and $11.6 \%$ of TOC, respectively, and therefore, total mineralizable $\mathrm{C}$ $\left(\mathrm{C}_{\text {total }}=\mathrm{C}_{\mathrm{R}}+\mathrm{C}_{\mathrm{S}}\right)$ of composts $\mathrm{A}, \mathrm{B}$, and $\mathrm{C}$ were $11.3,14.3$, and $13.8 \%$, respectively. Comparing with the $\mathrm{C}_{\% \mathrm{TOC}}$ of composts $\mathrm{A}(4.8 \%), \mathrm{B}(11.8 \%)$, and $\mathrm{C}(11.7 \%)$, the geater $\mathrm{C}_{\text {total }}$ values than the $\mathrm{C}_{\% \text { TOC }}$ indicates that mineralization of compost organic-C has not been completed during the 100-day incubation. Particularly for compost A, virtually the same value of $\mathrm{C}_{\% \mathrm{TOC}}$ to $\mathrm{C}_{\mathrm{R}}$ suggests that only rapid pool was undergone decomposition. Meanwhile, the higher $\mathrm{C}_{\% \mathrm{TOC}}$ than $\mathrm{C}_{\mathrm{R}}$ for composts $\mathrm{B}$ and $\mathrm{C}$ implies that mineralization of $C_{R}$ has been completed and some part of $C_{S}$ was experienced microbial decomposition.

The mineralization rate of the rapid pool $\left(\mathrm{k}_{\mathrm{R}}\right)$ ranged between 0.016 and $0.144 \mathrm{day}^{-1}$, and this was much greater than the mineralization rate of the slow pool $\left(\mathrm{k}_{\mathrm{s}}\right.$, from 0.003 to $0.026 \mathrm{day}^{-1}$ ) (Table 4). These indicate that the composts utilized in our study were heterogeneous, and consisted of organic $\mathrm{C}$ pools with differing biodegradability (Bernal and Kirchmann, 1992; Ajwa and Tabatabai, 1994; Bernal et al. 1998). For compost A, the much small values of both $\mathrm{k}_{\mathrm{R}}$ and $\mathrm{k}_{\mathrm{S}}$ well collaborates with the lower $\mathrm{C}_{\% \text { ТоC }}$ than other composts (Table 3).

\section{Conclusion}

Our study shows that $\mathrm{C}$ mineralization of compost was not correlated with SD but with other chemical indices associated with the progress of composting (maturity) such as $\mathrm{pH}, \mathrm{C} / \mathrm{N}$, extractable $\mathrm{C}$, and molar ratio of $\mathrm{NH}_{4}{ }^{+}$to $\mathrm{NO}_{3}^{-}$. The mal-linkage between $\mathrm{C}$ mineralization and $\mathrm{SD}$ of composts was attributed to the different types (rice hull and sawdust) of co-composting materials due to their dissimilar SD (sawdust $>$ rice hull) before initiation of composting. Therefore, it is suggested that both $\mathrm{SD}$ and other chemical indices ( $\mathrm{pH}, \mathrm{C} / \mathrm{N}$, extractable $\mathrm{C}$, and molar ratio of $\mathrm{NH}_{4}{ }^{+}$to $\mathrm{NO}_{3}{ }^{-}$) needs to be considered for better prediction of $\mathrm{C}$ mineralization from compost-amended soils.

\section{Acknowledgement}

This work was carried out with the support of "Cooperative Research Program for Agricultural Science \& Technology Development (Project No. PJ007409032011)", Rural Development Administration, Republic of Korea.

\section{References}

Ajwa, H.A. and M.A. Tabatabai. 1994. Decomposition of different organic materials in soils. Biol. Fertil. Soils 18:175-182.

Aslam, D., J.S. VanderGheynst, and T. Rumsey. 2008. Development of models for predicting carbon mineralization and associated phytotoxicity in compost-amended soil. Bioresour. Technol. 99:8735-8741.

Bernal, M.P. and H. Kirchmann. 1992. Carbon and nitrogen mineralization and ammonia volatilization from fresh, aerobically and anaerobically treated pig manure during incubation with soil. Biol. Fertil. Soils 13:135-141.

Bernal, M.P., M.A. Sanchez-Mondedero, C. Paredes, and A. Roig. 1998. Carbon mineralization from organic wastes at different composting stages during their incubation with soil. Agr. Ecosyst. Environ. 69:175-189.

Boyle, M. and E.A. Paul. 1989. Carbon and nitrogen mineralization kinetics in soil previously amended with sewage sludge. Soil Sci. Soc. Am. J. 53:99-103.

Busby, R.R., H.A. Torbert, and D.L. Gebhart. 2007. Carbon and nitrogen mineralization of non-composted and composted municipal solid waste in sandy soils. Soil Biol. Biochem. 39:1277-1283.

Castellanos, J.Z. and P.F. Pratt. 1981. Mineralization of manure nitrogen-Correlation with laboratory indices. Soil Sci. Soc. Am. J. 45:354-357.

Choi, W.J. and S.X. Chang. 2005. Nitrogen dynamics in cocomposted drilling wastes: Effects of compost quality and ${ }^{15} \mathrm{~N}$ fertilization. Soil Biol. Biochem. 37:2297-2305.

Courtney, R.G. and G.J. Mullen. 2008. Soil quality and barley growth as influenced by the land application of two compost types. Bioresour. Technol. 99:2913-2918.

Fierer, N. and J.P. Schimel. 2002. Effects of drying-rewetting frequency on soil carbon and nitrogen transformations. Soil Biol. Biochem. 34:777-787.

García-Gómez, A., M.P. Bernal, and A. Roig. 2003. Carbon mineralization and plant growth in soil amended with compost samples at different degrees of maturity. Waste Manage. Res. 21:161-171 
Gee, G.W. and J.W. Bauder. 1986. Particle-size analysis. p. 383412. In Campbell, G.S. et al. (ed.) Methods of soil analysis. Part 1. Physical and mineralogical methods. ASA and SSSA, Madison, WI, USA.

Hadas, A. and R. Portnoy. 1994. Nitrogen and carbon mineralization rates of composted manures incubated in soil. J. Environ. Qual. 23:1184-1189.

Helgason, B.L., F.J. Larney, and H.H. Janzen. 2005. Estimating carbon retention in soils amended with composted beef cattle manure. Can. J. Soil Sci. 85:39-46.

Kim, Y.J. W.J. Choi, S.S. Lim, J.H. Kwak, S.X. Chang, H.Y. Kim, K.S. Yoon, and H.M. Ro. 2008. Changes in nitrogen isotopic compositions during composting of cattle feedlot manure: Effects of bedding material type. Bioresour. Technol. 99:54525458.

Kirchmann, H. and A. Lundvall. 1993. Relationship between N immobilization and volatile fatty acids in soil after application of pig and cattle slurry. Biol. Fertil. Soils 15:161-164.

Leconte, M.C., M.J. Mazzarino, P. Satti, M.C. Iglesias, and F. Laos. 2009. Co-composting rice hulls and/or sawdust with poultry manure in NE Argentina. Waste Manage. 29:2446-245.

Levi-Minze, R., R. Riffaldi, and A. Saviozzi. 1990. Carbon mineralization in soil amended with different organic materials. Agri. Ecosyst. Environ. 31:325-335.

Lee, S.I., S.S. Lim, K.S. Lee, J.H. Kwak, J.W. Jung, H.M. Ro, and W.J. Choi. 2011. Kinetic responses of soil carbon dioxide emission to increasing urea application rate. Korean J. Environ. Agric. DOI: $10.5338 / \mathrm{KJEA2011.30.2.00.}$

Lópex, M., O. Huerta-Pujol, F.X. Xartínez-Farré, and M. Soliva.
2010. Approaching compost stability from Klason lignin modified method: chemical stability degree for $\mathrm{OM}$ and $\mathrm{N}$ quality assessment. Resour. Conserv. Recy. 55:171-181.

Mulvaney, R.L. 1996. Nitrogen - inorganic forms. p. 1123-1184. In Sparks, D.L. et al. (ed.) Methods of soil analysis. Part 3. Chemical methods. ASA and SSSA, Madison, WI, USA.

Nelson, D.W. and L.E. Sommers. 1996. Total carbon, organic carbon, and organic matter. p. 961-1010. In Sparks, D.L. et al. (ed.) Methods of soil analysis. Part 3. Chemical methods. ASA and SSSA, Madison, WI, USA.

Rochette, P., D.A. Angers, M.H. Chantigny, B. Gagnon, and N. Bertrand. 2006. In situ mineralization of dairy cattle manure as determined using soil-surface carbon dioxide fluxes. Soil Sci. Soc. Am. J. 70:744-752.

Sinha, M.K., D.P. Sinha, and H. Sinha. 1977. Organic matter transformations in soils. V. Kinetics of carbon and nitrogen mineralization in soil amended with different organic materials. Plant Soil 46:579-590.

Stamatiadis, S., M. Werner, and M. Buchanan. 1999. Field assessment of soil quality as affected by compost and fertilizer application in a broccoli field (San Benito County, California). Appl. Soil Ecol. 12:217-225.

Tittarelli, F. G. Petruzzelli, B. Pezzarossa, M. Civilini, A. Benedetti, and P. Sequi. 2007. Quality and agronomic use of compost. p. 49-66. In Diaz, L.F. et al. (eds) Compost science and technology. Elsevier, Amsterdam, Netherlands.

Wang, W.J., C.J. Smith, and D. Chen. 2004. Predicting soil nitrogen mineralization dynamics with a modified double exponential model. Soil Sci. Soc. Am. J. 68:1256-1265. 